\section{DINAMIKA PUTUS SEKOLAH DI KALANGAN PEKERJA ANAK DI KOTA MAKASSAR}

\section{Oleh : Sofyan, Andi Agustang, Andi Dodi M Putra A}

\begin{abstract}
Abstrak
Penelitian ini menelaah tentang pekerja anak informal yang putus sekolah di Kota Makassar. Secara umum penelitian ini bertujuan untuk memperoleh gambaran tentang fenomena putus sekolah di kalangan pekerja anak. Masalah pokok dalam penelitian ini adalah faktor-faktor non ekonomi (aspirasi, akses, dan layanan pendidikan) yang turut mendorong terjadinya putus sekolah di kalangan pekerja anak. Faktor ekonomi dengan alasan biaya pendidikan yang sangat mahal menjadi kurang polpuler dengan adanya berbagai program pemerintah yang meringankan bahkan membebaskan biaya pendidikan dasar. Setelah sekian lama program tersebut diimplementasikan, ternyata angka putus sekolah masih tetap signifikan. Patut diduga bahwa faktor perspektif individual (aspirasi) dan perpektif persekolahan (akses dan layanan pendidikan) turut memberi andil yang cukup besar terhadap keputusan pekerja anak meninggalkan sekolah.
\end{abstract}

Kata Kunci: Aspirasi, akses, layanan, pekerja anak, putus sekolah.

\section{A. Pendahuluan}

Pandangan filosofis bahwa pendidikan merupakan hak asasi manusia merupakan dasar bagi penyelenggaraan program wajib belajar yang harus diikuti oleh semua warga negara Indonesia. UUD 1945 dan Undang-Undang No. 20 Tahun 2003 tentang Sisdiknas menetapkan setiap warga negara Indonesia wajib menyelesaikan pendidikan dasar 9 tahun dan biayanya ditanggung oleh pemerintah. Wajar dikdas 9 tahun adalah prasyarat yang harus dipenuhi agar semua manusia Indonesia bisa menjadi pembelajar sepanjang hayat. Target Program Wajib Belajar Pendidikan Dasar Sembilan Tahun di Indonesia, yaitu meningkatkan partisipasi pendidikan dasar dengan indikator kinerja pencapaian APK jenjang SLTP/MTs mencapai 90 persen paling lambat pada 2008, dan meningkatkan mutu pendidikan dasar yang pada saat ini masih di bawah standar nasional.

Kebijakan pelaksanaan program wajib belajar minimal untuk tingkat pendidikan dasar, selain untuk memenuhi tuntutan konstitusi, juga untuk memenuhi komitmen global, Millennium Development Goals (MDGs) yang menargetkan pada tahun 2015 semua negara telah mencapai Angka Partisipasi Kasar (APK) pendidikan dasar $100 \%$. Target MDGs menjamin semua anak di manapun, baik laki-laki maupun perempuan, dapat menyelesaikan pendidikan dasar pada 2015. Sementara sasaran peningkatan kualitas pendidikan tahun 2010 - 2015 adalah meningkatnya akses masyarakat terhadap pendidikan, dengan indikator angka partsipasi kasar (APK) SD $100 \%$, SMP $98,09 \%$, SMA 69,34\% dan PT 18\%; angka partisipasi sekolah (APS) usia 7-12 tahun 99,57\%, 13-15 tahun 96,64\%; dan angka melanjutkan sekolah dari SD ke SMP 94\% dan dari jenjang SMP ke SMA 90\%

Namun demikian, Indonesia termasuk salah satu negara berkembang yang sarat dengan persoalan putus sekolah di samping problem pendidikan yang lainnya. Dilihat secara persentase, jumlah total siswa yang putus sekolah dari SD atau SMP memang hanya berkisar 2 hingga 3 persen dari total jumlah siswa. Namun, persentase yang kecil tersebut menjadi besar jika dilihat angka sebenarnya. Jumlah anak putus sekolah SD setiap tahun rata-rata berjumlah 600.000 hingga 700.000 siswa. Sementara itu, jumlah mereka yang tidak menyelesaikan sekolahnya di SMP sekitar 150.000 sampai 200.000 orang.(A. Y. A. Agustang et al., 2021).

Data menunjukkan bahwa jumlah anak putus sekolah di Indonesia terus meningkat setiap tahunnya. Pada tahun 2006 jumlahnya masih sekitar 10.8 juta anak. Namun, setahun kemudian sudah bertambah sekitar $20 \%$ menjadi 11,7 juta jiwa. Lebih dari 1,1 juta anak memilih berhenti belajar di sekolah selama tahun 2007 . Artinya, setiap menit ada 4 anak putus sekolah di Indonesia. Salah satu faktor yang mempengaruhi tingginya angka putus sekolah itu adalah dorongan orangtua dari keluarga tidak mampu. Anak kemudian dikondisikan untuk mencari uang dan menambah penghasilan keluarga. (Rasyid et al., 2020). Sedikitnya 497.275 anak usia 13 - 15 tahun di Indonesia belum mendapat layanan pendidikan SMP/MTS karena faktor kemiskinan, geografi, budaya kawin muda, dan tidak sekolah (Agustang; Andi et al., 2020).

Berdasarkan data BPS Angka partisipasi sekolah (APS) di Indonesia untuk anak usia 13 - 15 tahun 2009 sekitar $85.45 \%$. Sementara itu angka partisipasi kasar (APK) PAUD pada tahun 2008 baru mencapai 50,62 persen dan APM SD/MI/sederajat/Paket A baru mencapai 95,14 persen. Sementara itu, APK SMP/MTs/sederajat/Paket B adalah sebesar 96,18 persen dan APK SMA/sederajat baru mencapai 64,28 persen. Di Sulawesi Selatan Berdasarkan sensus penduduk tahun 2010, untuk tahun 2009 APS Sulawesi Selatan untuk umur 7 - 12 tahun adalah 96,53 dan 80,96 untuk anak umur $13-15$ tahun. APK pendidikan di Sulawesi Selatan pada jenjang SD/MI pada tahun 2008 adalah sekitar 109,25\% sedangkan Angka Partisipasi Murni (APM) adalah sekitar 92,15\%. Pada jenjang SMP/MTs/sederajat pada tahun yang sama APK adalah sekitar $72,43 \%$ sedangkan APM adalah sekitar 60,62\%. Sedangkan Pada jenjang Sekolah Menengah APK adalah sekitar $52,47 \%$ dan APM adalah sekitar $41,47 \%$. Data tersebut di atas menunjukkan banyaknya siswa yang berusia di bawah usia (underage) dan di atas usia (overage) seharusnya pada jenjang sekolah masing-masing.

APS di Kota Makassar untuk penduduk usia 7 - 12 tahun pada tahun 2009 sebesar 96,90 persen, usia 13 - 15 tahun sebesar 85,60 persen, dan $16-18$ tahun sebesar 55,60 persen. Hal ini menunjukkan bahwa di Kota Makassar masih terdapat sekitar 3,10 persen penduduk usia 7 - 12 tahun, sekitar 14,40 persen penduduk usia 13 - 15 tahun dan sekitar 44,40 persen penduduk usia 16 - 18 tahun yang belum pernah sekolah atau tidak melanjutkan ke jenjang pendidikan yang lebih tinggi. Sedangkan APS pada tahun 2008 untuk anak umur 7 - 12 tahun adalah $97 \%$, anak umur $13-15$ tahun adalah sebesar $86.4 \%$, dan anak umur $16-18$ tahun sebanyak 65.7 \% (Sensus Penduduk, 2010). Data tersebut menunjukan adanya kecenderungan semakin tinggi jenjang pendidikan semakin tinggi pula angka putus sekolah dan semakin rendah APS. Hasil pengamatan Lembaga Swadaya Masyarakat (LSM) Kibar, sejak Januari-April 2011, dari 12 ribu anak yang putus sekolah, terbesar di Kota Makassar. Jumlahnya mencapai 7.000 anak atau 60 persen dari total jumlah anak tak sekolah. Empat puluh persen sisanya 
tersebar di seluruh kabupaten/kota di Sulawesi Selatan (Agustang. A, 2017)

Tingginya angka putus sekolah mengakibatkan rentangnya mereka terseret ke dalam dunia kerja. Menurut Fangidae (1993) bahwa banyak anak yang bekerja untuk membantu ekonomi rumah tangganya tidak lagi bersekolah alasan utamanya adalah faktor ekonomi khususnya masalah keuangan keluarga, hal ini tidak terdata, tapi dengan masih adanya anak-anak putus sekolah, ke mana lagi perginya kalau bukan bekerja membantu mencari nafkah untuk keluarga. (Nur et al., 2020)

Pekerja anak merupakan salah satu fenomena yang memang menjadi fokus perhatian dunia dalam beberapa tahun belakangan ini. Survei Pekerja Anak (SPA) dari BPS bekerjasama dengan ILO menemukan dari 58,8 juta anak Indonesia pada 2009, 1,7 juta jiwa diantaranya menjadi pekerja anak. Menurut catatan Komnas Perlindungan Anak, di 33 provinsi, jumlah pekerja anak terus meningkat. Tahun 2006 jumlahnya mencapai 3,2 juta dan menjadi 4,8 juta pada 2007. Tahun 2008 diperkirakan menjadi 6,3 juta. Perkiraan ini berdasarkan pola tahun-tahun sebelumnya. Sekitar 20-30 persen anak putus sekolah masuk ke sektor kerja dan menjadi pekerja, terutama yang putus sekolah di level SMP (Syaharuddin et al., 2021).

Di Sulawesi Selatan, (Sakernas 2009) terdapat sekitar 106,5 ribu anak usia 10-17 sebagai pekerja anak yang terdiri dari 65,8 persen pekerja anak laki-laki dan 34,2 persen anak perempuan. Sebanyak 19,9 persen pekerja anak tinggal di perkotaan dan 80,9 persen tinggal di pedesaan. Sementara itu menurut kelompok umur 24,4 persen anak berusia 10-12 tahun, 46,8 persen berusia 13-14 tahun dan 38,8 persen berusia 15-17 tahun. Berdasarkan hasil survei tersebut pekerja anak yang bekerja dan bersekolah mencapai 53,4 persen dan sisanya sekitar 46,6 persen putus sekolah atau tidak sekolah.

Salah satu persoalan dalam upaya penanggulangan pekerja anak adalah bahwa sampai saat ini belum tersedia data yang akurat dan aktual tentang jumlah pekerja anak di Makassar. Hasil survey Lembaga Perlindungan Anak (LPA) di sejumlah titik di Kota Makassar tentang jumlah pekerja anak mencatat sekitar 700 orang pekerja anak (Andi Agustang \& Oruh, 2021). Pada survey yang lain LPA Sulsel pada awal tahun 2010 mendapatkan bahwa sekitar 300 anak menjadi korban Eksploitasi Seks Komersial Anak (ESKA). Anak-anak tersebut dijebak atau terjebak menjadi Pekerja Seks Komersial (PSK) (Fajar, 6 Januari 2010). Sementara itu Dinas Sosial Kota Makassar memperkirakan terdapat sekitar 5.000 anak berprofesi sebagai pemulung, pengemis jalanan, kuli bangunan, dan penjual koran. Mereka rata-rata hidup menggelandang tanpa tempat tinggal.(SHERMINA ORUH \& ANDI AGUSTANG, 2015)

Penuntasan wajib belajar 9 tahun tidak akan dapat dilakukan tanpa memperhatikan persoalan pekerja anak. Anak-anak yang bekerja sambil sekolah rawan mengalami putus sekolah. Sebaliknya anak yang putus sekolah cenderung terdorong untuk menjadi pekerja anak. Pekerja anak merupakan anak usia sekolah yang termasuk dalam kategori Wajib Belajar 9 Tahun. Sehingga perlu upaya menyeluruh dalam penanggulangan kedua permasalahan tersebut. Menurut Suyanto dan Mashud (2002) bahwa partisipasi sekolah mempunyai hubungan resiprokal dengan status pekerjaan anak. Anak yang gagal dalam pendidikan (drop out) lebih terdorong untuk bekerja, dan sebaliknya anak yang bekerja sambil sekolah cenderung menurun prestasinya, atau mudah mengalami drop out (dalam Darwin, 2009).
Namun demikian, ketika di perhadapkan pada pilihan anak harus sekolah atau bekerja, sebagian orang tua lebih mengarahkan anaknya untuk bekerja karena dapat menghasilkan sesuatu, sementara sekolah yang ditempuh dengan berbagai kesulitan serta biaya mahal, begitu tamat tidak menjamin anak-anak memperoleh pekerjaan yang layak. Faktanya jutaan anak-anak kini dipaksa atau pun terpaksa kehilangan masa kecil dan masa bermain mereka. Dengan alasan ekonomi, sebagian besar dari mereka terpaksa menjadi pekerja di bawah umur yang sarat akan resiko yang sangat membahayakan.

Menurut Maria Fransiska Subagyo (1986) dalam Suyanto, kemelaratan diakui merupakan salah satu penyebab timbulnya kasus pelajar putus sekolah. Namun demikian, di luar itu faktor yang harus diperhatikan adalah cara keluarga mendidik anak, hubungan orang tua dengan anak, dan sikap atau aspirasi orang tua terhadap pendidikan. Di samping itu, tingkat pendidikan orang tua si anak itu sendiri juga tidak dapat dilupakan. Hansen,1972 (dalam Mifflen. 1986:230) mengatakan bahwa "pencapaian pendidikan dapat dikemukakan dalam bentuk sederhana sebagai efek dari tiga variable yakni : kesanggupan, aspirasi, dan kesempatan". Ketiga variabel tersebut di atas pada dasarnya memang menjadi faktor yang berpengaruh dalam keterlibatan masyarakat pada pendidikan. Hal yang sama di kemukakan A lolo (2008) dalam study baseline di beberapa tempat termasuk Makassar bahwa putus sekolah (dropout) adalah fenomena multidimensional karena tidak ada faktor tunggal yang mempengaruhi keberadaannya. Kondisi ekonomi tidak lagi dianggap sebagai satu-satunya alasan meskipun dipandang sebagai faktor dominan. Berat beban kurikulum, metode pengajaran tidak menarik, perilaku guru terhadap siswa, kurangnya pemahaman orang tua mengenai peran pendidikan, budaya tradisional dan kepercayaan, dan pesimisme terhadap manfaat belajar bagi masa depan anakanak dan lain-lain mempengaruhi potensi dropout siswa sulit dihilangkan atau diberantas.

Pada tahun 2008 Direktorat Pengawasan Tenaga Kerja Perempuan dan Anak, Kemnakertrans, meluncurkan program pengurangan pekerja anak melalui pendidikan sekolah gratis, namun banyak anak tetap tidak mau bersekolah. Dari sejumlah 4.850 anak yang pada tahun 2008 telah ditarik dari tempat kerjanya, sebanyak 790 anak bisa kembali sekolah di pendidikan formal, sedangkan anak yang ditarik ke pendidikan keterampilan sebanyak 824 orang, dan sisanya ditarik ke paket $A, B, C$ atau pendidikan layanan khusus. Meskipun demikian, program tersebut masih jauh dari harapan, karena yang benar-benar berhasil kembali ke pendidikan hanya 500 -an anak dari sebanyak 4.850 orang anak. (BP-PNFI Makassar)

A. Lolo (2008) pada study baseline di beberapa kabupaten/kota di Sulawesi Selatan termasuk Makassar bahwa harapan akan masa depan anak setelah menempuh pendidikan turut mempengaruhi partisipasi pendidikan masyarakat. Hal yang sama dinyatakan Martina dan Agustian (1999) bahwa salah satu masalah yang terkait dengan anak jalanan adalah pola pikir yang pendek dan simple akibat rendahnya pendidikan. ILO dan Unicef, melaporkan hal senada bahwa banyak orang tua yang miskin pendidikan tidak mengetahui nilai pendidikan jangka panjang, manfaat ekonomi jangka panjang, dibandingkan manfaat ekonomi jangka pendek dengan mempekerjakan anak. (Usman, 2004)

Persoalan putus sekolah yang banyak dialami pekerja anak juga disinyalir bersumber dari struktur pendidikan itu sendiri, yakni ketimpangan jumlah lembaga pendidikan atau sekolah yang kecenderungannya semakin tinggi jenjang 
pendidikan semakin kurang daya tampungnya. Daya tampung sekolah yang tidak seimbang antar jenjang mengakibatkan sebagian anak tidak terserap pada jenjang pendidikan selanjutnya. Di Makassar pada tahun 2010, untuk SD dari jumlah siswa yang mengikuti UAS-BN sebanyak 27.283 orang (Tribun News.Com). Sementara, untuk tingkatan SMP/ MTS dari 42 sekolah negeri dengan ketersediaan ruang kelas 935 , telah disiapkan daya tampung siswa sebanyak 11.528 orang (Makassar Terkini, 2010). Sebagian besar tamatan SD (sekitar 15.000) harus bersaing di sekolah-sekolah swasta yang belum tentu mampu menampung semuanya. Sementara itu untuk tahun 2011 kapasitas SMP Negeri di Makassar adalah 12.000 sementara peminat berjumlah sekitar 31.000 orang. Persaingan untuk masuk ke sekolah negeri sangat ketat. (Tribun Timur, $30 \mathrm{Mei}$ 2011)

Hal tersebut menjadi semakin rumit karena adanya ekslusi dalam sistem persekolahan di Indonesia, yakni ketidakikutsertaan anak dalam proses pendidikan dan berbagai aspek kehidupan lainnya. Bourguignon; Loury 1999, (dalam Thomas 2000) mengemukakan bahwa "ekslusi sosial mengurangi insentif individu untuk bersekolah dan bekerja". Kebijakan tentang sekolah unggulan seperti Sekolah Berstandar linternasional (SBI), Sekolah Standar Nasional (SSN), sekolah unggulan, kelas khusus, dan lainlain patut diduga sebagai salah satu faktor membatasi akses pendidikan masyarakat, khususnya kalangan bawah karena adanya persyaratan yang sangat ketat dalam sistem penerimaaan siswa baru. Bukan hanya aspek IQ-nya tapi juga aspek ekonomi yang akan membuat mereka tersingkir dari persaingan yang ketat. Ekslusi sekolah-sekolah tertentu justru membuat jarak antara siswa dengan sekolah mereka menjadi jauh, karena tidak semua anak yang tinggal di sekitar sekolah ekslusif tersebut dapat mengaksesnya.

Fasilitas layanan pendidikan juga masih belum merata, khususnya pada jenjang pendidikan menengah dan tinggi. Di samping faktor ekonomi, masih belum meratanya penyediaan layanan pendidikan juga berpengaruh terhadap kondisi rendahnya partisipasi pendidikan pada jenjang menengah dan tinggi. Selain itu, baik di jenjang pendidikan formal maupun nonformal masih terdapat masalah pada penyediaan layanan pendidikan khusus terutama untuk anak-anak yang memerlukan perhatian khusus (children with special needs), di antaranya mereka yang mempunyai kelainan fisik, emosional, mental, sosial, dan/atau memiliki potensi kecerdasan dan bakat istimewa. (Renstra Depdiknas, 2010 - 2014)

Dinamika dunia kerja telah menyeret anak-anak untuk beraktivitas secara tidak wajar sesuai dengan apa yang diharapkan masyarakat. Permasalahan pekerja anak merupakan salah satu dimensi penelantaran hak anak untuk tumbuh dan berkembang secara wajar. Interpretasinya, bukan berarti bahwa anak tidak boleh bekerja sama sekali. Dalam rangka proses adaptasi dan transformasi pengetahuan dan keterampilan kerja serta melatih anak untuk mandiri, sudah menjadi tradisi bagi masyarakat kita untuk melibatkan anak membantu orangtua bekerja di samping tugas sebagai pelajar. Namun ketika terjadi pergeseran pola perlakuan dari proses transformasi dan sosialisasi kerja kepada anak menjadi mempekerjakan anak dan mengabaikan hak anak untuk sekolah, tentu saja sangat bertentangan dengan hukum dan hak anak. Kecenderungan ini cukup mengkhawatirkan, karena hal tersebut akan melanggengkan mata rantai kemiskinan.
Berdasarkan uraian di atas tidak dapat dipungkiri bahwa faktor ekonomi memang dominan dalam menentukan partisipasi pendidikan/sekolah anak. Akan tetapi, ekonomi bukanlah satu-satunya yang berpengaruh, ada banyak faktor lain yang ikut menentukan partisipasi pandidikan anak. Hadirnya program pemerintah dalam bentuk pendidikan gratis dan bantuan langsung sekolah berupa dana Bantuan Operasioal Sekolah (BOS) berimplikasi pada berkurangnya beban biaya sekolah masyarakat. Namun demikian implementasi program ini ternyata masih menyisakan angka putus sekolah yang cukup signifikan. Berarti, ada faktorfaktor lain, baik faktor sosial, budaya, kebijakan, struktur, demografi, psikososial atau faktor lainnya yang ikut mempengaruhi putus sekolah dan terjunnya anak-anak ke dunia kerja. Kondisi inilah yang menarik perhatian peneliti untuk menelusuri lebih jauh tentang fenomena putus sekolah khususnya pada pekerja anak non formal di Makassar.

\section{B. Perumusan Masalah}

Berdasarkan dugaan di atas, maka rumusan masalah (problem statement) dalam penelitian ini adalah sebagai berikut:

1. Aspirasi pendidikan keluarga pekerja anak di Makassar rendah sehingga partisipasi pendidikan mereka juga rendah.

2. Akses pekerja anak terhadap lembaga pendidikan (sekolah) di Makassar terbatas sehingga partisipasi mereka rendah.

3. Layanan pendidikan bagi pekerja anak di Makassar kurang adaptif sehingga mendorong mereka untuk putus sekolah (drop out).

\section{Tujuan Penelitian}

Penelitian ini bertujuan untuk mengungkap dan menganalisis secara komprehensif tentang partisipasi pendidikan pekerja anak. Secara khusus penelitian ini bertujuan untuk menggali, menghimpun, dan menganalisis berbagai informasi empirik serta faktor-faktor yang terkait dengan pekerja anak putus sekolah. Secara rinci penelitian ini bertujuan untuk mengetahui:

1. Aspirasi pendidikan pekerja anak dalam kaitannya dengan partisipasi pendidikan mereka di Makassar.

2. Perspektif pekerja anak terhadap akses pendidikan dalam kaitannya dengan partisipasi pendidikan mereka di Makassar.

3. Perspektif pekerja anak terhadap layanan pendidikan dan faktor pendorong untuk putus sekolah (drop out) di Makassar.

\section{Kerangka Teori}

1. Konsep dan Determinan Pekerja Anak

Menurut Supeno (2008) dalam masyarakat kita banyak variasi dalam memandang anak atau nilai anak. Pertama, adalah anak sebagai amanah. Kedua, nilai anak sebagai historis. Ketiga, nilai anak sebagai barang komoditas (ekonomi). Keempat, pandangan bahwa anak merupakan asset keluarga, masyarakat dan bangsa. Pandangan masyarakat tentang nilai anak akan mempengaruhi orang tua di dalam menerapkan pola asuh. Pandangan anak sebagai sebagai barang komoditas menjadi dasar bagi orang tua untuk mengeksploitasinya. Hal inilah yang mendorong para orang tua untuk mempekerjakan anak-anak mereka. Anak dipandang sebagai komoditas yang dapat menghasilkan uang untuk membantu perekonomian keluarga, sehingga mengabaikan hak tumbuh kembang anak-anak secara wajar. (Oruh, 2018) 
Pada keluarga miskin, anak merupakan jaminan hidup keluarga karena tenaganya memberikan sumbangan penghasilan keluarga. Penelitian oleh LeVine menunjukkan bahwa tujuan mempunyai anak pada masyarakat miskin lebih bersifat kuantitatif, artinya semakin banyak anak akan semakin kuat jaminan sosial-ekonomi keluarga (LeVine dkk, 1988, dalam Darwin, 2009).

Secara umum pekerja atau buruh anak adalah anakanak yang melakukan pekerjaan secara rutin untuk orang tuanya, untuk orang lain atau untuk dirinya sendiri yang membutuhkan sejumlah besar waktu, dengan menerima imbalan atau tidak (Suyanto, 2003:3 dalam Darwin, 2009). Dalam Konvensi ILO No. 138 mengenai Usia Minimun Untuk Diperbolehkan Bekerja ditegaskan bahwa usia minimun untuk boleh bekerja adalah tidak boleh kurang dari usia tamat sekolah wajib dan paling tidak tidak boleh kurang dari 15 tahun.

Ada dua kelompok keterlibatan anak dalam pekerjaan. Kelompok pertama adalah kelompok anak yang melakukan pekerjaan tanpa memperoleh upah dalam rangka membantu orang tua, melatih keterampilan, belajar bertanggung jawab atau dalam rangka hal lainnya. Dengan pekerjaan tersebut anak masih dapat menikmati hak-haknya secara baik dan tidak terganggu proses tumbuh kembangnya. Sedangkan kelompok kedua adalah kelompok anak yang melakukan pekerjaan di bawah perintah orang lain dengan mendapat upah. Dalam melakukan pekerjaan ini anak tereksploitasi, baik secara fisik, mental, sosial maupun intelektualnya. Dengan pekerjaan tersebut anak tidak dapat menikmati hakhaknya secara baik dan terganggu proses tumbuh kembangnya. Kelompok kedua ini disebut sebagai pekerja anak dan banyak terlibat dalam berbagai bentuk pekerjaan terburuk anak.(Supeno,2008)

Hernando de Soto dalam bukunya Masih Ada Jalan Lain (1991) menyebutkan bahwa sektor informal merupakan altematif paling memungkinkan bagi kelompok miskin untuk meraih kesejahteraan yang diinginkan. Dalam kondisi seperti itulah keluarga miskin yang membawa serta anak-anak usia sekolah ke dalam kegiatan ekonomi tidak jarang memperoleh perlakuan sosial yang salah dari pihak-pihak ekstemal. Dari sinilah kemiskinan kota menyimpan sejumlah masalah sosial yang semakin rumit.

Pada keluarga miskin, keputusan untuk bekerja sebagian datang dari anak sendiri, tetapi sebagian lain karena keinginan orang tua. Penelitian oleh Suyanto dan Mashud (2000:33 dalam Darwin, 2009) menemukan bahwa lebih dari separuh orang tua menghendaki anaknya membantu pekerjaan orang tua dengan maksud-maksud sosial edukatif meski pada kenyataannya hal ini tetap mengakibatkan banyak anak lebih tertarik menekuni pekerjaan daripada sekolahnya. Sebagian kecil lainnya memaksa anak-anaknya bekerjabaik dalam lingkungan keluarga maupun kepada orang lainuntuk tujuan ekonomi.

Sekalipun kemiskinan merupakan pendorong utama anak-anak terjun ke dunia kerja, tetapi kenyataan menunjukkan bahwa tidak semua orang miskin membiarkan anak-anaknya terjun ke dunia kerja. Berarti ada faktor-faktor lain, baik faktor sosial, budaya, demografi, atau psikososial yang ikut mempengaruhi anak-anak terjun ke dunia kerja. Putranto (1995) dengan menyebutkan bahwa masalah kemiskinan bukanlah satu-satunya faktor penyebab timbulnya masalah pekerja anak. Dengan demikian, ada anggapan bahwa permasalahan pekerja anak akan hilang dengan sendirinya apabila permasalahan kemiskinan dapat diatasi, merupakan pandangan yang keliru.
Hasil baseline study yang dilakukan oleh Agustang, A. (1999) tentang pekerja anak di beberapa kabupaten/kota Sulawesi Selatan menemukan bahwa selain faktor kemiskinan, munculnya pekerja anak juga disebabkan karena faktor lain yakni sosial, budaya, tradisi, melanjutkan bisnis keluarga dan lain-lain. Kerja di usia dini juga merupakan kebanggaan dan dianggap oleh orang tua sebagai anak-anak sebagai pelatihan bagi anak-anak untuk menjadi mandiri di masa depan. Semangat perdagangan yang dimiliki oleh orang-orang dari Bugis dan Makassar telah mempengaruhi orang tua untuk memotivasi anak-anak mereka untuk belajar bagaimana mencari uang dari awal sebelum meraka menjadi orang dewasa.

\section{Determinan Putus Sekolah}

Problem putus sekolah merupakan fenomena yang terjadi di negara-negara miskin ataupun di negara-negara berkembang. Fenomena ini terjadi pada seluruh jenjang pendidikan formal, mulai dari sekolah dasar sampai dengan pendidikan tinggi. Putus sekolah adalah proses berhentinya siswa secara terpaksa dari suatu lembaga pendidikan tempat dia belajar. Anak Putus sekolah yang dimaksud disini adalah terlantarnya anak dari sebuah lembaga pendidikan formal, yang disebabkan oleh berbagai faktor.

Terdapat dua faktor yang mempengaruhi anak untuk bersekolah, yaitu faktor internal (dalam diri) dan faktor eksternal (luar diri) siswa. Aspek internal meliputi kemampuan, minat, motivasi, nilai-nilai dan sikap, ekspektasi (harapan), dan persepsi siswa tentang sekolah. Pada aspek eksternal meliputi latar belakang ekonomi orangtua, persepsi orangtua tentang pendidikan, jarak sekolah dari rumah, hubungan guru-murid, usaha yang dilakukan pemerintah (meliputi pemberian bantuan dan pengadaan sarana dan prasarana). Banyaknya siswa-siswa yang tidak berhasil dalam belajar, termasuk banyaknya anak-anak putus sekolah bisa dilihat dari kedua aspek tersebut (Hasanuddin, 2000). Faktor budaya juga ikut berperan seperti kawin muda bagi anak perempuan dan bisnis keluarga yang menyebabkan anak usia sekolah meninggalkan sekolah. Fenomena kontemporer juga menunjukkan bahwa DO atau putus sekolah juga didapati di kalangan anak dari keluarga kaya atau mampu secara ekonomi.

\section{a. Perspektif individual}

Secara individual ada dua faktor yang berpengaruh adalah faktor status sosial dan faktor resiko. Menurut kajian Sukmadinata (1994), faktor utama penyebab anak putus sekolah adalah kesulitan ekonomi atau karena orang tua tidak mampu menyediakan biaya bagi sekolah anak-anaknya (status sosial). Di samping itu, tidak jarang terjadi orang tua meminta anaknya berhenti sekolah karena mereka membutuhkan tenaga anaknya untuk membantu ekonomi orang tua.

Periset membagi konstruknya menjadi dua kategori: resiko sosial dan resiko akademik. Resiko sosial meliputi faktor-faktor demografis terkait dengan kemungkinan yang lebih besar untuk mendapati berbagai kesulitan di seputar masalah sekolah, ras atau etnisitas, usia, status minoritas, bahasa, gender, pendapatan keluarga, pendidikan orang tua, dan struktur keluarga. Siswa dari keluarga dengan pendapatan rendah biasanya mengalami DO pada tingkat yang lebih tinggi daripada yang dialami oleh kelompok siswa yang berasal dari keluarga dengan pendapatan tinggi, demikian pula. Resiko akademik yang merujuk pada perilaku dan kinerja sekolah mencerminkan manifestasi sebenarnya 
dari berbagai permasalahan terkait sekolah (Caterall, 1988). Perilaku seperti ini memberi ciri pada proses DO. Misalnya, siswa yang pada akhirnya mengalami DO seringkali memiliki sejarah kemangkiran dan tinggal kelas (Lee \& Burkam, 1992), kesulitan akademik (Bryk \& Thum, 1989), dan ketidakterkaitan lebih umum dari kehidupan sekolah (Entwistle dkk., 1997, dalam Mutrofin 2009)

Meninggalkan sekolah (DO) dapat benar-benar mewakili upaya akhir siswa untuk memecahkan permasalahan seperti itu (Croninger \& Lee, 2001). Bahkan anak-anak remaja pun dapat terkena risiko akademik yang berakhir dengan DO apabila pada awal masa sekolahnya sudah menunjukkan perilaku sekolah seperti rendahnya nilai, harapan pada pendidikan yang juga rendah, ditempatkan pada pendidikan khusus, tinggal kelas dini (early grade retention), dan berbagai permasalahan disiplin. Sebagaimana risiko sosial, risiko akademik pun bersifat kumulatif (Mutrofin 2009).

\section{b. Perspektif persekolahan}

Sistem persekolahan merupakan salah satu faktor yang memberi sumbangan pada kondisi yang mendorong anak untuk putus sekolah, disamping faktor individual. Berbagai unsur sekolah yang terkait dengan siswa secara langsung atau tidak langsung mempunyai peluang untuk berkontribusi dalam keputusan anak untuk putus sekolah. Beberapa kajian kualitatif atau interaktif mempertimbangkan bagaimana sekolah itu sendiri terlibat dalam praktik atau menciptakan kondisi yang mendorong siswa dengan tipe tertentu agar keluar (tidak melanjutkan pelajaran) sekolah, khususnya mereka yang memperlihatkan faktor resiko sosial dan akademik sebagaimana di bahas di atas.

Ada tiga hal yang menjadi faktor pendorong putus sekolah dalam perspektif persekolahan yakni struktur sekolah, organisasi akademik sekolah dan organisasi sosial sekolah. Struktur sekolah yang dimaksud dalam hal ini adalah unsur-unsur yang terlibat pada suatu sekolah yang membentuk suatu sistem. Nasution, 2009 mengemukakan bahwa struktur sekolah terdiri dari (1) meterialnya (jumlah orang, pria, wanita, dewasa, anak, guru, murid dan sebagainya), (2) hubungan antara bagiannya (apa yang diharapkan guru dari murid dan sekolahnya, dan sebagainya, (3) hakikat masyarakat itu sebagai keseluruhan yakni cara bagian-bagiannya menjadi kesatuan yang bulat agar dapat menjalankan fungsinya.

\section{c. Perspektif organisasi sosial}

Baik kajian kualitatif maupun kajian kuantitatif menegaskan bahwa siswa yang meninggalkan sekolah sebelum lulus sering dipandang sebagai siswa yang kurang mendapat dukungan sosial sebagai akibat dari tindakannya. Siswa yang tidak puas dengan laporan sekolah menjadi putus hubungan dengan guru, bahkan setelah berupaya keras mendapatkan bantuan dari personalia sekolah. Siswa yang tidak merasa dilibatkan mengklaim bahwa guru tidak peduli pada mereka, kurang tertarik dengan apa yang mereka kerjakan disekolah, dan tidak hendak membantu dalam menagatasi permasalahan mereka (Valenzuela, 1999 dalam Mutrofin 2009).

Hasil wawancara dangan pelaku DO pada saat mereka telah meninggalkan sekolah mengungkapkan bahwa separuh di antaranya menyatakan mereka keluar sebenarnya karena alasan sosial, karena ketidakcocokan mereka dengan guru dan siswa lain. Kajian-kajian kualitatif juga menunjukkan bahwa hubungan-hubungan sosial positif dapat menciptakan insentif besar bagi siswa untuk kembali ke sekolah; bahkan bagi siswa yang melaporkan bahwa tugas sekolah berat, dan ekspektasi tidak mudah dipenuhi (Fine, 1991, dalam Mutrofin, 2009). Modal sosial yang diukur dengan berbagai hubungan di antara siswa dengan tenaga guru dan berdasarkan laporan oleh guru mengenai pembicaraanya dengan siswa di luar kelas berhubungan sangat erat dengan DO, bahkan setelah faktor risiko sosial dan akademik siswa turut diperhitungkan (Crononger \& Lee, 2001 dalam Mutrofin, 2009)

\section{E. Perspektif Teori Pilihan Rasional dan Tindakan Voluntaristik.}

Teori pilihan rasional bertolak dari asumsi maksimalisasi kegunaan (utility maximazation). Tiang penyangga masyarakat adalah individu; pelaku rasional yang selalu bertindak untuk kepentingannya sendiri. Teori ini memusatkan perhatian pada aktor. Aktor dipandang sebagai manusia yang mempunyai tujuan atau mempunyai maksud. Artinya aktor mempunyai tujuan dan tindakannya tertuju pada upaya untuk mencapai tujuan itu.Aktor pun dipandang mempunyai pilihan (atau nilai, keperluan). Teori pilihan rasional tidak menghiraukan apa yang menjadi pilihan atau apa yang menjadi sumber pilihan aktor. Yang penting adalah kenyataan bahwa tindakan dilakukan untuk mencapai tujuan yang sesuai dengan tingkatan pilihan aktor. (Ritzer,2004; 357)

Meski teori pilihan rasional berawal dari tujuan atau maksud aktor, namun teori ini memperhatikan sekurangkurangnya dua pemaksa utama tindakan. Pertama adalah keterbatasan sumber. Aktor mempunyai sumber yang berbeda maupun akses yang berbeda terhadap sumber daya yang lain. Bagi aktor yang mempunyai sumber daya yang besar, pencapaian tujuan mungkin relatif mudah. Tetapi bagi aktor yang mempunyai sumber daya sedikit, pencapaian tujuan mungkin sukar atau mustahil sama sekali. (Ritzer,2004)

Berkaitan dengan keterbatasan sumber daya ini adalah pemikiran tentang kesempatan (opportuny cost) atau "biaya yang berkaitan dengan rentetan tindakan berikutnya yang sangat menarik namun tak jadi dilakukan" (Friedman dan Hechter, 1988:22, dalam Ritzer, 2004). Dalam mengejar tujuan tertentu, aktor tentu memperhatikan biaya tindakan berikutnya yang sangat menarik yang tak jadi dilakukan itu. Seorang aktor mungkin memilih untuk tidak mengejar tujuan yang bernilai sangat tinggi bila sumber dayanya tak memadai, bila peluang untuk mencapai tujuan itu mengancam peluangnya untuk mencapai tujuan berikutnya yang sangat bernilai. Aktor dipandang berupaya mencapai keuntungan maksimal, dan tujuan mungkin meliputi penilaian gabungan antara peluang untuk mencapai tujuan utama dan apa yang telah dicapai pada peluang yang tersedia untuk mencapai tujuan kedua yang paling bernilai.(Ritzer,2004).

Sumber pemaksa kedua atas tindakan aktor individual adalah lembaga sosial. Seperti dinyatakan Friedman dan Hechter, aktor individual biasanya akan merasakan tindakannya diawasi sejak lahirnya hingga mati oleh aturan keluarga dan sekolah; hukum dan peraturan; kebijakan tegas; gereja; sinagoge dan mesjid; rumah sakit dan pekuburan. Dengan membatasi rentetan tindakan yang boleh dilakukan oleh individu, dengan dilaksanakannya aturan permainan meliputi norma, hukum, agenda, dan aturan pemungutan suara secara sistematis memengaruhi akibat sosial (dalam Ritzer, 2004:358). Hambatan kelembagaan ini menyediakan baik sanksi positif maupun sanksi negatif yang 
membantu mendorong aktor untuk melakukan tindakan tertentu dan menghindarkan tindakan yang lain.

Salah satu tipe tindakan sosial menurut Weber adalah tindakan rasional instrumental (zweckrational). Merupakan tindakan rasional yang paling tinggi yang meliputi pertimbangan dan pilihan yang sadar yang berhubungan dengan tujuan tindakan itu dan alat yang dipergunakan untuk mencapainya. Individu dilihat sebagai memiliki macammacam tujuan yang mungkin diinginkannya, dan atas dasar suatu kriterium menentukan suatu pilihan di antara tujuantujuan yang saling bersaingan ini. Individu itu lalu menilai alat yang mungkin dapat dipergunakan untuk mencapai tujuan yang dipilih tadi. Hal ini mungkin mencakup pengumpulan informasi, mencatat kemungkinan-kemungkinan serta hambatan-hambatan yang terdapat dalam lingkungan, dan mencoba untuk meramalkan konsekuensi-konsekuensi yang mungkin dari beberapa alternative tindakan itu. Akhirnya suatu pilihan dibuat atas alat yang dipergunakan yang kiranya mencerminkan pertimbangan individu atas efisiensi dan efektivitasnya. Sesudah tindakan itu dilaksanakan, orang itu dapat menentukan secara objektif sesuatu yang berhubungan dengan orang lain.

Sebaliknya tipe tindakan tradisional merupakan tindakan yang bersifat non rasional. Kalau individu memperlihatkan perilaku karena kebiasaan, tanpa refleksi yang sadar atau perencanaan, perilaku seperti ini digolongkan sebagai tindakan tradisional. Individu itu akan membenarkan atau menjelaskan tindakan itu, kalau diminta, dengan hanya mengatakan bahwa dia selalu bertindak dengan cara seperti itu atau perilaku seperti itu merupakan kebiasaan baginya. Apabila kelompok-kelompok atau seluruh masyarakat didominasi oleh orientasi ini, maka kebiasaan dan institusi mereka diabsahkan atau didukung oleh kebiasaan atau tradisi yang sudah lama mapan sebagai kerangka acuannya, yang diterima begitu saja tanpa persoalan. Satu-satunya pembenaran yang perlu adalah bahwa, "inilah cara yang sudah dilaksanakan oleh nenek moyang kami, dan dengan demikian pula nenek moyang mereka sebelumnya; ini adalah cara yang sudah begini dan akan selalu begini terus" Weber melihat bahwa tipe tindakan ini sedang lenyap karena meningkatnya rasionalitas instrumental. (Johnson, 1986:220-221)

\section{b. Teori tindakan voluntaristik (voluntaristic action)}

Dalam The Structure of Social Action(1937), Parsons menunjukkan teori aksi (action theory) di mana ini menuju titik sentral konsep perilaku voluntaristik. Konsep ini mengandung pengertian kemampuan individu menentukan cara dan alat dari sejumlah alternatif yang tersedia dalam rangka mencapai tujuan.

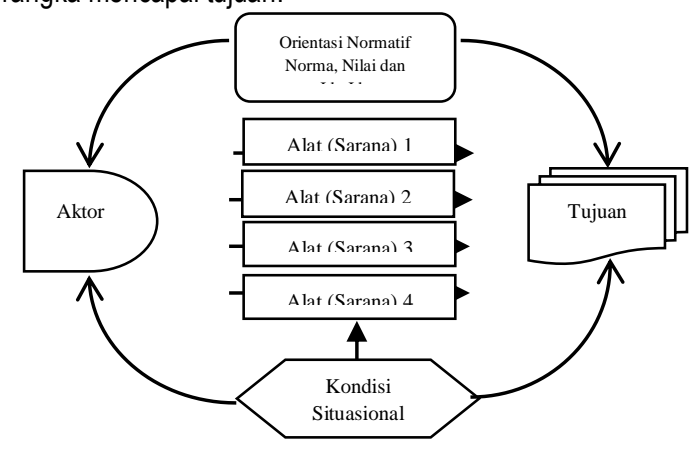

Gambar 2. Model perilaku voluntaristik Parsons Sumber :Jonathan Turner, The Structure of Sociological Theory (dalam Susilo 2008:114).
Individu yang memiliki tujuan disebut sebagai aktor.Tidak ada individu yang bertindak tanpa memiliki tujuan tertentu. Tujuan merupakan keseluruhan keadaan konkret di masa depan yang diharapkan, sejauh relevan dengan kerangka acuan tindakan. Bisa dikatakan bahwa aktor terlibat dalam pengejaran, realisasi, atau pencapaian tujuan itu. Karenanya, ia merupakan proses dalam waktu. Oleh karena itu, demi memfasilitasi ini, ia memerlukan seperangkat alat. Alat bias dipilih secara acak, juga bias bergantung pada kondisi tindakan. Alat tersebut bias muncul satu persatu, bias juga muncul secara berbarengan. (Susilo 2008:114)

Parsons membuat konsep "voluntaristic" sebagai sebuah proses pengambilan keputusan subyektif dari para pelaku individual (aktor), tetapi ia melihat keputusan seperti itu sebagai hasil akhir dari pertimbangan parsial terhadap jenis hambatan tertentu, baik hambatan normatif maupun hambatan situasional. Tindakan "voluntaristik" menurut Parsons mencakup elemen-elemen dasar sebagai berikut : (1) adanya pelaku yang di dalam konsepsi Parsons merupakan pelaku individual (pelaku perorangan) ; (2) yang diasumsikan sebagai orang yang sedang mengejar tujuan (goal) ; dan (3) pelaku juga dianggap memiliki beberapa alternatif cara atau alat untuk mencapai tujuan itu; (4) pelaku dihadapkan pada berbagai macam kondisi dan situasional, seperti pembentukan biologisnya, keturunannya, dan juga berbagai hambatan ekologi eksternal, yang dapat mempengaruhi pemilihan alat untuk mencapai tujuannya itu ; (5) pelaku juga diatur oleh seperangkat nilai, norma dan ideide lainnya dimana ide-ide ini mempengaruhi apa yang dianggap sebagai tujuan dan alat, atau cara apa yang dipilih untuk meraih tujuan tersebut; sehingga, (6) tindakan "voluntaristik" dengan demikian mencakup pembuatan keputusan subyektif tentang alat atau cara, yang digunakan untuk meraih tujuan; dimana semuanya itu dipengaruhi oleh value, norms, other idea, kondisi dan situasional tertentu.

Hampir semua tindakan manusia adalah sukarela (voluntary). Tindakan itu adalah produk dari suatu keputusan untuk bertindak, sebagai hasil dari pikiran. Hampir semua yang kita lakukan adalah hasil dari memilih tindakan dengan suatu cara tertentu bukan cara lain. Lebih lanjut, ini adalah pilihan purposif, atau berorientasi pada tujuan. Kita memilih di antara banyak pilihan karena, sebagai manusia, kita mampu mengarah kepada tujuan atau hasil dan mengambil tindakan untuk mencapainya. Oleh karena itu, hampir semua tindakan manusia adalah tindakan yang disengaja: kita mewujudkan tindakan tertentu dalam rangka mencapai tujuan yang dikehendaki.(Jones, 2009: 25)

Sosiologi pilihan rasional menurut Heckarthorn memandang bahwa, memilih itu sebagai tindakan yang bersifat rasional. Jadi artinya, Teori Pilihan Rasional sangat menekankan pada prinsip "ëfisiensi" di dalam mencapai tujuan suatu tindakan. Sementara, Teori Tindakan Sosial (Talcott Parsons) sangat deterministik dan hanya menekankan pada proses pemilihan "means" (cara) di dalam mencapai tujuan suatu tindakan. Dalam kerangka semacam inilah maka dipandang penting untuk mengintegrasikan Rational Choice Theory dengan Voluntaristic Theory of Action Talcott Parsons, agar teori Voluntaristik memiliki "frame work" yang jelas dan menjadi lebih tajam untuk digunakan menganalisis "proses pengambilan keputusan tingkat individu untuk meninggalkan sekolah dan menjadi pekerja anak". 


\section{Dinamika Putus Sekolah di Kalangan Pekerja Anak Di Kota Makassar}

Partisipasi sekolah mempunyai hubungan resiprokal dengan status pekerjaan anak. Anak yang gagal dalam pendidikan (drop out) lebih terdorong untuk bekerja, dan sebaliknya anak yang bekerja sambil sekolah cenderung menurun prestasinya, atau mudah mengalami drop out (Suyanto dan Mashud, 2000: 22, dalam Darwin, 2009).

Menurut Pitirim A. Sorokin, di dalam mobilitas sosial secara vertikal dapat dilakukan lewat beberapa saluran terpenting antara lain melalui lembaga-lembaga pendidikan. Lembaga pendidikan dinilai merupakan saluran paling konkret dari mobilitas sosial vertikal, bahkan lembaga pendidikan formal dianggap sebagai social elevator yang bergerak dari kedudukan yang paling rendah ke kedudukan paling tinggi. (dalam Suyanto, 2004:190)

Kegiatan pendidikan yang dilakukan oleh masyarakat merupakan salah satu kegiatan yang dapat meningkatkan human capital. Menurut Bellante, 1983 (dalam Muhardi 2006) human capital adalah dana atau pengeluaran individu yang di investasikan dalam stok tenaga penghasilannya atau disebut dengan earning power. Oleh karena itu, terdapat tiga kategori biaya dalam human capital menurut Ehrenberg, 2003 (dalam Muhardi 2006), yaitu:

1. Pengeluaran yang langsung yang dialokasikan untuk keperluan sekolah, seperti buku, komputer, dan peralatan sekolah lainnya;

2. Pendapatan yang hilang (forgone earning), yaitu kesempatan untuk memperoleh uang dari suatu pekerjaan karena waktunya dialokasikan untuk sekolah; dan

3. Kehilangan fisik karena belajar sering mengalami kesulitan dan membosankan.

Ketiga kategori biaya tersebut diringkas oleh Perkins, 2001(dalam Muhardi 2006) kedalam biaya eksplisit dan biaya implisit.Point 1 yang dikemukakan Ehrenberg termasuk ke dalam biaya eksplisit (actual outlay of cash), sedangkan point 2 dan 3 termasuk ke dalam biaya implisit.

Baik Bellante (1983), Ehrenberg (2003) maupun Perkins (2001) menyatakan bahwa keputusan individu untuk melanjutkan sekolah ditentukan oleh perbandingan biaya dan manfaat yang di diskonto ke periode waktu sekarang dengan asumsi individu tersebut berperilaku rasional dan sempurnanya informasi tentang biaya pendidikan dan penghasilan di pasar kerja. Menurut Perkins (2001) dengan menggunakan asumsi sebelumnya, keputusan individu untuk melanjutkan sekolah atau bekerja tergantung pada tingkat pengembalian internal (internal rate of return)

Sementara Hansen,1972 (dalam Mifflen. 1986:230) mengatakan bahwa "pencapaian pendidikan dapat dikemukakan dalam bentuk sederhana sebagai efek dari tiga variable yakni : kesanggupan, aspirasi, dan kesempatan". Ketiga variabel tersebut di atas pada dasarnya memang menjadi faktor yang berpengaruh dalam keterlibatan masyarakat pada pendidikan.

\section{Aspirasi pendidikan keluarga pekerja anak putus sekolah}

Hasil penelitian menunjukkan bahwa aspirasi pendidikan pada umumnya memiliki pandangan yang cukup positif terhadap pendidikan, namun demikian hal ini tidak berbanding lurus dengan sikap mereka terhadap pendidikan anak-anaknya. Mereka kurang memiliki motivasi untuk mendukung secara penuh anaknya untuk menekuni sekolahnya. Mereka cenderung pasrah dengan kondisi yang dialami anaknya sekarang. Hal tersebut sesuai dengan konsep yang dikemukaan oleh Schneider, (1986), bahwa posisi anak kelas pekerja (kelas bawah) berbeda dari posisi anak di kelas lainnya. Anak kelas bawah jarang didorong untuk "berhasil" atau hidup sesuai dengan apa yang dianggap norma-norma kepantasan pada kelas yang lebih tinggi. Ini bukan berarti bahwa si anak tidak diharapkan untuk berperilaku sesuai dengan nilai-nilai tertentu, tetapi nilai-nilai tersebut adalah nilai-nilai kelasnya.

Pada umumnya juga mereka pesimis dengan harapan akan tujuan pendidikan anak-anaknya. Masa depan anak melalui pendidikan mereka ragukan. Mereka tidak yakin kalau anak-anaknya akan mendapatkan pekerjaan yang lebih baik jika mereka terus bersekolah. Prediksi kemampuan mereka menyekolahkan anak yang rata-rata hanya sampai jenjang SMA. Karena berdasarkan pengalaman mereka anak-anak di sekitar lingkungannya yang berijazah SMA juga sulit mendapatkan pekerjaan. Beberapa informan mengaku tidak pernah membayangkan kalau seandainya dia sekolah akan sampai kuliah/sarjana.

Berdasarkan temuan tersebut di atas, maka jika ditinjau dari segi teori termasuk dalam kategori budaya kemiskinan yang dikemukakan oleh Lewis (1988), di mana mereka memiliki aspirasi-aspirasi yang rendah sebagai bentuk adaptasi realistik. Menurut Oscar Lewis (1988), karakteristik kebudayaan kemiskinan antara lain adalah tidak berminat pada pendidikan formal yang berdimensi masa depan. Ada kecenderungan mereka memilih caranya sendiri berdasarkan kondisi dan situasi yang berlaku di kalangan mereka. Dengan melibatkan anak bekerja lebih cepat, mereka yakin akan mampu menbuat ia mandiri di masa yang akan datang, meskipun dengan pendidikan yang sangat minim. Kondisi dan situasi mereka mempengaruhi keputusan mereka untuk meninggalkan sekolah dan menjadi pekerja anak untuk menjamin kelangsungan hidupnya di masa depan.

Bekerja merupakan pilihan bagi pekerja anak untuk bertahan hidup demi masa depan mereka. Di mana melalui cara ini mereka disosialisasikan budaya kerja untuk belajar mandiri sejak kecil. Pilihan ini dianggap lebih efektif dan lebih menjamin kepastian mereka untuk menyonsong masa depan mereka. Karena melalui pendidikan formal mereka merasa pesimis untuk jaminan masa depan anaknya. Dimana resiko gagal dalam pendidikan selalu mengancam dengan berbagai resiko sosial dan resiko akademik

Tekanan "kemiskinan dan struktur" mengakibatkan menguatnya budaya kemiskinan dikalangan pekerja anak dan keluarganya. Mereka cenderung pasrah (fatalism) dan kurang berminat pada pendidikan karena perasaan akan selalu gagal. Aspirasi pendidikan aktor dan keluarganya relatif rendah, dan muncul sikap pesimis akan masa depan dengan pendidikan. Sikap dan komitmen mereka terhadap pendidikan juga menjadi rendah, sehingga kurang atau bahkan tidak berminat/memiliki motivasi untuk lanjut sekolah.

\section{Akses Pendidikan Pekerja Anak}

Akses aktor terhadap informasi program pendidikan secara umum sangat minim. Informasi-informasi umum tentang program pemerintah belum mampu mereka akses dengan baik, demikian juga dengan informasi-informasi yang terkait dengan pendidikan di sekolah. Hal ini menunjukkan bahwa sosialisasi program pendidikan selama ini kurang menyentuh masyarakat secara keseluruhan, terutama sekali kelompok masyarakat miskin. Beberapa informan mengaku bahwa informasi tentang Program Wajib Belajar 9 Tahun kurang mereka pahami maksud dan tujuannya. Demikian juga dengan pendidikan gratis, pada umumnya informan sering mendengar tentang program pendidikan gratis, tapi 
mereka tidak tahu tentang item-item yang digratiskan dan sampai jenjang sekolah mana anak-anak gratis.

Akses mereka terhadap program bantuan pemerintah dalam bentuk beasiswa juga sulit. Bantuan pendidikan bagi kelompok keluarga miskin sulit diakses salah satunya karena persyaratan administratif yang cukup rumit. Beberapa informan mengakui akan sulitnya mengakses sekolah negeri, karena terbatasnya kuota yang tersedia, sementara jumlah pendaftar sangat banyak. Apalagi sekolah-sekolah yang favorit, seperti sekolah SSN, RSBI ataupun sekolah unggulan lainya, karena sekolah jenis ini mempersyaratkan standar nilai di atas rata-rata. Hal ini tentu bertentangan dengan konsep pemerataan dan perluasan akses yang dicanangkan oleh pemerintah. Kondisi ini juga tidak selaras dengan semangat Undang-Undang No. 20 Tahun 2003 Sistem Pendidikan Nasional pasal 5 ayat 1 yang menyebutkan bahwa setiap warga negara mempunyai hak yang sama untuk memperoleh pendidikan yang bermutu.

Data Dinas Pendidikan Makassar menunjukkan, untuk tingkat SMP pada tahun 2011, daya tampung dari 42 SMP negeri yang ada hanya 11.608 siswa, sedangkan jumlah pendaftar mencapai 24.000 pendaftar. Artinya, jumlah lulusan SD yang bisa diterima di SMP negeri kurang dari $50 \%$ jumlah pendaftar. (A. Agustang \& Oruh, 2017). Dengan demikian, maka memang akan terjadi persaingan yang sangat ketat untuk mengakses sekolah negeri. Sementara pada sekolah swasta, masyarakat akan terbebani dengan pembayaran yang masih diberlakukan pihak sekolah. Di Makassar, angka partisipasi sekolah untuk tingkat SD sudah tinggi dan bahkan angka partisipasi murni sudah mendekati Universal Primary Education yang dipatok pada angka 100\% pada tahun 2015. Meskipun demikian untuk tingkat SMP, angka partisipasi sekolah masih relatif rendah dan ini terutama terjadi pada kelompok masyarakat miskin. Upaya untuk meningkatkan transisi dari SD ke SMP merupakan salah satu hal pokok yang perlu dilakukan untuk meningkatkan angka partisipasi pendidikan dasar yang masih relatif rendah. (Laporan MDGs Kota Makassar, 2010)

Temuan tersebut di atas menunjukkan adanya keterbatasan sumber daya yang tersedia, sementara peminat sangat banyak. Kondisi ini menurut teori pilihan rasional mengakibatkan sulitnya akses aktor tententu terhadap sumber daya tersebut. Hal ini mendorong, mereka untuk menentukan pilihan lain untuk mencapai tujuannya. Informan mungkin memilih untuk tidak mengejar tujuan yang bernilai sangat tinggi bila sumber dayanya tak memadai, bila peluang untuk mencapai tujuan itu mengancam peluangnya untuk mencapai tujuan berikutnya yang sangat bernilai. Hal ini menurut teori pilihan rasional bahwa terdapat sekurangkurangnya dua pemaksa utama tindakan. Salah satunya adalah keterbatasan sumber. Aktor mempunyai sumber yang berbeda maupun akses yang berbeda terhadap sumber daya yang lain. Bagi aktor yang mempunyai sumber daya yang besar, pencapaian tujuan mungkin relatif mudah. Tetapi bagi aktor yang mempunyai sumber daya sedikit, pencapaian tujuan mungkin sukar atau mustahil sama sekali. (Ritzer, 2004). Sementara Weber menyebutnya sebagai salah satu bentuk tindakan rasionalitas praktis yang oleh Kalberg didefenisikan sebagai "setiap jalan yang memandang dan menilai aktivitas-aktivitas duniawi dalam kaitannya dengan kepentingan individu yang murni pragmatis dan egoistis". Orang yang mempraktikkan rasional praktis menerima realitas yang ada dan sekadar mengkalkulasikan cara termudah untuk mengatasi kesulitan yang mereka hadapi. (Oruh et al., 2019)
Akses keluarga informan terhadap pendidikan juga masih relatif rendah. Program pendidikan yang dicanangkan oleh pemerintah tidak tersosialisasikan dengan baik kepada mereka, sehingga pemahaman dan kesadaran mereka akan pendidikan sangat minim. Ketimpangan fasilitas dan ekslusi sekolah juga membatasi akses mereka terhadap pendidikan. Demikian juga dengan struktur pendidikan dasar dengan manajemen terpisah yang menyulitkan dan memberi peluang bagi mereka untuk putus sekolah.

\section{Layanan pendidikan di sekolah}

Hasil penelitian menunjukkan bahwa layan pendidikan yang diterima oleh para informan semasa sekolah belum adaptir dengan kebutuhan dan kondisi mereka. Beban belajar yang diperuntukkan bagi siswa yang normal tentu akan terasa berat bagi mereka, karena kesulitan untuk membagi waktu belajar atau mengerjakan tugas-tugasnya. Pada kasus di atas, beberapa informan merasa berat akan beban belajar yang harus mereka selesaikan, bukan hanya jumlah mata pelajaran, akan tetapi juga tugas-tugas per mata pelajaran yang kadang bertumpuk antara satu dengan yang lain. Sehingga perlu adanya koordinasi antara para guru dalam pemberian tugas agar tidak terlalu membebani siswa. Kajian-kajian kualitatif juga menunjukkan bahwa hubunganhubungan sosial positif dapat menciptakan insentif besar bagi siswa untuk kembali ke sekolah; bahkan bagi siswa yang melaporkan bahwa tugas sekolah berat, dan ekspektasi tidak mudah dipenuhi (Andi Agustang, 2010) dan (Fine, 1991, dalam Mutrofin, 2009). Modal sosial yang diukur dengan berbagai hubungan di antara siswa dengan tenaga guru dan berdasarkan laporan oleh guru mengenai pembicaraanya dengan siswa di luar kelas berhubungan sangat erat dengan DO, bahkan setelah faktor risiko sosial dan akademik siswa turut diperhitungkan (Crononger \& Lee, 2001 dalam Mutrofin, 2009) (Andi Agustang \& Oruh, 2021)

Hal ini tersebut diakui oleh salah seorang guru yang mengajar di SMP Terbuka di sekolahnya yakni MD, bahwa kemampuan siswa yang sekolah sambil bekerja berbeda dengan siswa murni lainnya. Berdasarkan pengalamannya mengajar di kelas SMP terbuka yang siswanya rata-rata pekerja anak, ia mendapatkan bahwa ketika memberikan tugas yang agak berat maka siswa tidak mampu untuk menyelesaikan. Bahkan banyak yang tidak masuk sekolah ketika tiba waktunya tagihan tugas itu wajib disetorkan. Sebaliknya, jika tugas yang diberikan termasuk dalam kategori ringan maka mereka akan tetap masuk sekolah. Oleh karena itu, setiap guru harus memahami kemampuan siswa tersebut, untuk menyesuaikan dengan beban belajar yang diberikan.

Layanan bimbingan konseling juga belum mampu membantu informan untuk mengatasi berbagai adaptasi khususnya kesulitan belajar. Layanan yang mereka terima bersifat umum dan tidak ada layanan khusus bagi siswa yang mempunyai masalah. Kondisi ini tentu kurang membantu bagi siswa yang mempunyai problem khusus terkait dengan kelangsungan proses pembelajarannya atau bahkan kelangsungan sekolahnya. Sekolah juga kurang peduli dengan adanya siswa mereka yang berhenti, kurang memiliki kepedulian untuk membimbing siswa-siswa yang memiliki masalah agar tidak berlarut-larut dan akhirnya berhenti sekolah. Demikian juga dengan kegiatan ekstra-kurikuler yang belum mampu memfasilitasi kebutuhan informan sesuai dengan kebutuhan minat dan bakatnya.

Organisasi sosial di sekolah informan yakni hubungan antara siswa dan guru serta dengan siswa lainnya. Respon guru terhadap kesalahan informan dengan hukuman dan 
bahkan kekerasan membuat informan antipati pada guruguru tertentu. Pemberian hukuman tidak disertai dengan pemahaman terhadap siswa akan hasil yang diharapkan oleh guru yang bersangkutan. Demikian juga hubungan dengan sesama siswa yang menjadi buruk karena masih terjadinya konflik antar siswa di sekolah (Yudhar et al., 2021).

Baik kajian kualitatif maupun kajian kuantitatif menegaskan bahwa siswa yang meninggalkan sekolah sebelum lulus sering dipandang sebagai siswa yang kurang mendapat dukungan sosial sebagai akibat dari tindakannya. Siswa yang tidak puas dengan laporan sekolah menjadi putus hubungan dengan guru, bahkan setelah berupaya keras mendapatkan bantuan dari personalia sekolah (Andi Agustang, 2021). Siswa yang tidak merasa dilibatkan mengklaim bahwa guru tidak peduli pada mereka, kurang tertarik dengan apa yang mereka kerjakan disekolah, dan tidak hendak membantu dalam menagatasi permasalahan mereka (Valenzuela, 1999 dalam Mutrofin 2009) (Ufie et al., 2021). Hasil wawancara dangan pelaku DO pada saat mereka telah meninggalkan sekolah mengungkapkan bahwa separuh di antaranya menyatakan mereka keluar sebenarnya karena alasan sosial, karena ketidakcocokan mereka dengan guru dan siswa lain (Caterall, 1998, dalam Mutrofin 2009) dan (Andi Agustang et al., 2021)

Layanan fasilitas yang disediakan sekolah juga dirasakan informan belum maksimal. Penyediaan buku paket masih terbatas, sementara layanan perpustakaan tidak menyediakan semua jenis buku yang dibutuhkan siswa. Fasilitas umum sekolah seperti toilet sebenarnya cukup tersedia, tetapi kurang terawat sehingga tidak nyaman untuk digunakan. Demikian juga dengan meja dan kursi yang menurut beberapa informan sudah ada yang rusak tapi masih digunakan. Menurut informan, jumlah siswa yang terlalu banyak dalam satu kelas juga cukup mengganggu dan membuat anak-anak tidak nyaman dalam belajar. Selain karena terlalu rapat, juga karena sulitnya guru mengontrol semua siswa pada saat pembelajaran. Sehingga terkadang banyak siswa yang usil dengan mengganggu temannya yang sedang serius mengikuti pembelajaran (Andi Agustang, 2005).

Layanan pendidikan yang diterima oleh aktor sewaktu sekolah belum adaptif dengan kondisi dan kebutuhannya. Sekolah belum mampu memberikan layanan yang adaptif dengan kebutuhan dan karakteristik aktor. Interaksi edukatif yang berlangsung belum mampu membantu aktor untuk beradaptasi dengan situasi pembelajaran (Oruh et al., 2017).

\section{F. Penutup}

Berdasakan pada hasil penelitian di atas, maka dapat disimpulkan bahwa tekanan "kemiskinan dan struktur" mengakibatkan menguatnya budaya kemiskinan dikalangan pekerja anak dan keluarganya. Mereka cenderung pasrah (fatalism) dan kurang berminat pada pendidikan karena perasaan akan selalu gagal. Aspirasi pendidikan aktor dan keluarganya relatif rendah, dan muncul sikap pesimis akan masa depan dengan pendidikan. Sikap dan komitmen mereka terhadap pendidikan juga menjadi rendah, sehingga kurang atau bahkan tidak berminat/memiliki motivasi untuk lanjut sekolah. Akses keluarga informan terhadap pendidikan juga masih relatif rendah. Program pendidikan yang dicanangkan oleh pemerintah tidak tersosialisasikan dengan baik kepada mereka, sehingga pemahaman dan kesadaran mereka akan pendidikan sangat minim. Ketimpangan fasilitas dan ekslusi sekolah juga membatasi akses mereka terhadap pendidikan. Demikian juga dengan struktur pendidikan dasar dengan manajemen terpisah yang menyulitkan dan memberi peluang bagi mereka untuk putus sekolah. Layanan pendidikan yang diterima oleh aktor sewaktu sekolah belum adaptif dengan kondisi dan kebutuhannya. Sekolah belum mampu memberikan layanan yang adaptif dengan kebutuhan dan karakteristik aktor. Interaksi edukatif yang berlangsung belum mampu membantu aktor untuk beradaptasi dengan situasi pembelajaran (A. Agustang \& Oruh, 2017).

Akumulasi dari berbagai tekanan struktur di atas, memberi peluang dan mendorong pekerja anak untuk meninggalkan sekolah. Mereka lebih berpikir pragmatis dan sekedar mencari solusi terbaik untuk menghadapi tekanantekanan tersebut. Orientasi masa depan dengan sekolah menjadi pudar karena resiko kegagalan (sosial dan akademik) selalu mengancam eksistensi mereka di sekolah (Masni et al., 2021).

\section{B. Saran}

Berdasakan pada kesimpulan hasil penelitian di atas, maka dapat dirumuskan beberapa saran sebagai berikut :

1. Upaya penanggulangan pekerja anak yang putus sekolah harus dilakukan dengan pendekatan holistik. Permasalahan tersebut tidak akan selesai hanya dengan program pendidikan gratis atau membebaskan mereka dari pembayaran. Harus ada "intervensi komunitas" untuk mensosialisasikan program pemerintah dalam rangka meningkatkan kesadaran masyarakat, khususnya kelompok miskin agar memiliki motivasi dan komitmen yang tinggi atas kelangsungan pendidikan anak.

2. Perluasan dan pemerataan akses pendidikan harus diimplementasikan secara intensif, dengan memberi kepastian kepada masyarakat akan akses terhadap pendidikan yang bermutu. Pentingnya mengkaji sistem manajemen satu atap antara SD dan SMP agar dapat memberi jaminan kepada peserta didik alumni SD akan keberlanjutan pendidikannya ke jenjang SMP. Konsep ini penting untuk mendukung Program Wajib Belajar 9 Tahun.

3. Layanan pendidikan bagi pekerja anak harus adaptif dengan kebutuhan dan kondisinya. Struktur akademik/kurikulum dan pemberian tugas-tugas harus disesuaikan dengan kamampuan dan waktu mereka untuk menuntaskannya. Oleh karena itu, perlu diupayakan untuk mengkaji suatu kurikulum khusus yang beban belajarnya adaptif dengan situasi dan kondisi pekerja anak.

Referensi:

Agustang; Andi, Suardi, Mutiara; Ainun, \& Ramlan; Herdianty. (2020). SOCIAL PRENEUR

DALAM PENANGGULANGAN KEMISKINAN DI KECAMATAN BISSAPPU KABUPATEN BANTAENG. Jurnal Pengabdian Masyarakat, 3(3), 331-342. https://doi.org/10.31604/jpm.v3i2.331-342

Agustang. A. (2017). Sufisme dan Kemiskinan Kultural Pada Komunitas Nelayan Dipesisir Teluk Bone Kecamatan Sibulue. Jurnal Pemikiran Islam., 14(3), 342-364.

Agustang, A., \& Oruh, S. (2017). Factors affecting of heropnam of mental disorders in Dadi Regional Hospital in South Sulawesi Province. Man in 
India, 97(11), 233-244.

Agustang, A. Y. A., Herman, H., Said, M., \& Agustang, A. (2021). Upaya Guru IPS Dalam Meningkatkan Motivasi Belajar Siswa Pada Masa Covid 19 Di SMP. Phinisi Integration Review, 4(1), 144-149.

Agustang, Andi. (2005). DEFLEKSI SOSIO KULTURAL MASYARAKAT MARITIM KE ARAH KEPENTINGAN PEMBANGUNAN (Studi Kasus Pada Komunitas Nelayan di Kabupaten Selayar Propinsi Sulawesi Selatan). Universitas Padjadjaran.

Agustang, Andi. (2010). SUFISME DAN KEMISKINAN KULTURAL PADA KOMUNITAS NELAYAN DI PESISIR TELUK BONE KECAMATAN SIBULUE. $A L$ FIKR, 14, 342-364. http://journal.uinalauddin.ac.id/index.php/alfikr/article/view/2327

Agustang, Andi. (2021). Filosofi Research Dalam Upaya Pengembangan Ilmu. OSF Preprints.

Agustang, Andi, \& Oruh, S. (2021). KESEJAHTERAAN PSIKOLOGIS (studi Pada Dewasa Madya Yang Belum Menikah Di Kota Makassar).

Agustang, Andi, Suardi, S., Putra, A. D. M., \& Oruh, S. (2021). Pemberdayaan Guru Mata Pelajaran Sosiologi Melalui Literasi Digital Berbasis Quick Response Code di Kecamatan Bissappu Kabupaten Bantaeng. Abdi: Jurnal Pengabdian Dan Pemberdayaan Masyarakat, 3(2), 175-188. https://doi.org/10.24036/abdi.v3i2.120

Masni, M., Oruh, S., \& Agustang, A. (2021). Tinjauan Sosiologis Penanganan Kasus Kekerasan Dalam Rumah Tangga Menurut UU PKDRT Oleh Pengadilan Negeri Pangkep. Jurnal Sosialisasi: Jurnal Hasil Pemikiran, Penelitian Dan Pengembangan Keilmuan Sosiologi Pendidikan, $8,108-117$.

Nur, S., Andi Agustang, \& Arlin Adam. (2020). Uninhabitable Home: Portraits of Poverty in Cities. Indonesian Journal of Social and Environmental Issues (IJSEI), 1(3 SE-), 234238. https://doi.org/10.47540/ijsei.v1i3.81

Oruh, S. (2018). KAU MAU KEMANA? ( Refleksi Sosiologis terhadap Integritas Upaya Kesehatan Jiwa ). 1-3.

Oruh, S., Agustang, A., \& Alim, A. (2017). Kejadian Heropnam Gangguan Jiwa Dan Faktor Yang Mempengaruhi Pada Rumah Sakit Khusus Daerah Dadi Provinsi Sulawesi Selatan. July.

Oruh, S., Theresia, M., \& Agustang, A. (2019). KESEJAHTERAAN PSIKOLOGIS. Researchgate.Net.

Rasyid, R., Agustang, A., Agustang, A. T. P., Bastiana B., \& Najamuddin, N. (2020). Analisis Faktor Yang Mempengaruhi Status Kemiskinan Rumah Tangga Pada Wilayah Central Bussiness District (CBD) di Kota Makassar. Majalah Geografi Indonesia, 34(1), 43-52.
SHERMINA ORUH, \& ANDI AGUSTANG. (2015). PENGARUH PENGETAHUAN KELUARGA, STIGMA MASYARAKAT DAN KEPATUHAN MINUM OBAT TERHADAP KEKAMBUHAN PENYAKIT GANGGUAN JIWA DI KOTA MAKASSAR. In $D k$ (Vol. 53, Issue 9, pp. 1689-1699). https://doi.org/10.1017/CBO9781107415324.00 4

Syaharuddin, S., Agustang, A., Idkhan, A. M., \& Rifdan, R. (2021). STRATEGI DINAS SOSIAL DALAM PENANGANAN ANAK JALANAN DI KOTA MAKASSAR. JISIP (Jurnal Ilmu Sosial Dan Pendidikan), 5(4).

Ufie, A., Oruh, S., \& Agustang, A. (2021). Maintaining Social Harmony Through Historical Learning Based on Local Wisdom of Indigenous Peoples in Maluku. Historia: Jurnal Pendidik Dan Peneliti Sejarah, 5(1), 31-40.

Yudhar, A. N., Agustang, A., \& Sahabuddin, J. (2021) Habituation of character values in junior high school students. Cypriot Journal of Educational Sciences, 16(2), 659-668. https://doi.org/10.18844/CJES.V16I2.5642 